\title{
Recent advances in understanding hepatic drug transport
}

\section{[version 1; peer review: 2 approved]}

\author{
Bruno Stieger ${ }^{1}$, Bruno Hagenbuch ${ }^{2}$
}

${ }^{1}$ Department of Clinical Pharmacology and Toxicology, University Hospital Zurich, University of Zurich, Zurich, 8091, Switzerland

${ }^{2}$ Department of Pharmacology, Toxicology and Therapeutics, The University of Kansas Medical Center, Kansas City, KS, 66160, USA

V1 First published: 06 Oct 2016, 5(F1000 Faculty Rev):2465

https://doi.org/10.12688/f1000research.9466.1

Latest published: 06 Oct 2016, 5(F1000 Faculty Rev):2465

https://doi.org/10.12688/f1000research.9466.1

\section{Abstract}

Cells need to strictly control their internal milieu, a function which is performed by the plasma membrane. Selective passage of molecules across the plasma membrane is controlled by transport proteins. As the liver is the central organ for drug metabolism, hepatocytes are equipped with numerous drug transporters expressed at the plasma membrane. Drug disposition includes absorption, distribution, metabolism, and elimination of a drug and hence multiple passages of drugs and their metabolites across membranes. Consequently, understanding the exact mechanisms of drug transporters is essential both in drug development and in drug therapy. While many drug transporters are expressed in hepatocytes, and some of them are well characterized, several transporters have only recently been identified as new drug transporters. Novel powerful tools to deorphanize (drug) transporters are being applied and show promising results. Although a large set of tools are available for studying transport in vitro and in isolated cells, tools for studying transport in living organisms, including humans, are evolving now and rely predominantly on imaging techniques, e.g. positron emission tomography. Imaging is an area which, certainly in the near future, will provide important insights into "transporters at work" in vivo.

\section{Keywords}

drug disposition, drug metabolism, hepatocellular drug uptake, solute carrier

\section{Open Peer Review}

Approval Status

$\checkmark$

1

2

version 1

06 Oct 2016

Faculty Reviews are review articles written by the prestigious Members of Faculty Opinions. The articles are commissioned and peer reviewed before publication to ensure that the final,

published version is comprehensive and accessible. The reviewers who approved the final version are listed with their names and affiliations.

\section{Amal Khalil Kaddoumi, University of Louisiana at Monroe, Monroe, USA}

2. Richard Kim, University of Western Ontario, London, Canada

Any comments on the article can be found at the end of the article. 
Corresponding authors: Bruno Stieger (bruno.stieger@uzh.ch), Bruno Hagenbuch (bhagenbuch@kumc.edu)

Competing interests: The authors declare that they have no competing interests.

Grant information: Bruno Stieger is supported by the Swiss National Science foundation (grant 310030_166563) and by the SNF National Center for Competence TransCure (University of Berne, Berne, Switzerland). Bruno Hagenbuch is funded by the National Institutes of Health grant GM077336.

Copyright: $\odot 2016$ Stieger B and Hagenbuch B. This is an open access article distributed under the terms of the Creative Commons Attribution License, which permits unrestricted use, distribution, and reproduction in any medium, provided the original work is properly cited.

How to cite this article: Stieger $B$ and Hagenbuch $B$. Recent advances in understanding hepatic drug transport [version 1; peer review: 2 approved] F1000Research 2016, 5(F1000 Faculty Rev):2465 https://doi.org/10.12688/f1000research.9466.1

First published: 06 Oct 2016, 5(F1000 Faculty Rev):2465 https://doi.org/10.12688/f1000research.9466.1 


\section{Role of drug transporters in drug disposition}

Mammals, including humans, have evolved an elaborate array of organs, which are interconnected by the circulatory system. All organs are composed of cells, which can be considered as minimal functional units of organs. Cells need to strictly control their internal milieu and this is achieved by the plasma membrane, which acts as a barrier against the external milieu. The selective crossing of this barrier is mediated, among others, by transport proteins.

Drug disposition involves absorption, distribution, metabolism, and elimination of a drug. In order to enter the systemic circulation, orally administered drugs need to cross the epithelial barrier in the intestine and any drug in the systemic circulation needs to cross more than one cell membrane in order to be metabolized and/or eliminated ${ }^{1}$. Given the barrier function of cell membranes, it is plausible that solutes including drugs and their metabolites need specific transport systems to cross this barrier in either direction ${ }^{2}$. It should, however, be pointed out that this issue remains somewhat controversial $^{3}$. In addition, it is very likely that most, if not all, drug transporters are also involved in the handling of endogenous solutes and as such may serve in inter-organ communication ${ }^{1}$.

The liver is the major site of drug metabolism and accounts for about $70 \%$ of drug elimination in humans ${ }^{4}$. Consequently, this overview focuses on hepatocellular transporters. Overviews of hepatocellular drug transporters are found $\mathrm{in}^{4-6}$. From an overview perspective, drug transporters can be divided into two large super families: the solute carrier (SLC) superfamily mediates the cellular uptake of drugs in general, while members of the ATP-binding cassette $(A B C)$ superfamily mediate the cellular efflux of drugs and their metabolites ${ }^{7}$. As many of these transporters (in particular the SLC transporters involved in hepatocellular drug uptake, such as organic anion transporting polypeptides [OATPs], organic anion transporters [OATs], and organic cation transporters [OCTs]) are multi-specific, drug-drug interactions at these transporters may lead to altered pharmacokinetics and subsequently to adverse drug actions and/or to therapeutic failure ${ }^{8,9}$.

Consequently, there are numerous approaches used to develop models and tools for predicting drug-drug interactions and to incorporate this information into the process of drug development ${ }^{10}$. While the crystal structures of human cytochrome P450 (CYP) enzymes were determined a while ago ${ }^{11}$, such information on human drug transporters is lacking to date ${ }^{12}$. This makes the in vitro prediction of pharmacokinetic drug-drug interactions challenging at best. Hence, currently, alternate approaches for studying drugdrug interactions are actively being pursued. One includes innovative cell culture approaches often termed "organ-on-a-chip"13,14.

Traditionally, drug-drug interaction studies early in drug development are performed in vitro. If, for example, an interaction at the cellular uptake level is to be considered, cell lines stably expressing drug transporters can be used. However, such experiments may be difficult owing to the complex kinetic properties of most drug transporters. For illustration, many OATPs transport their different substrates via different substrate-binding sites ${ }^{15}$. Hence, testing for interactions of commonly used drugs with model substrates of OATP1B1 has yielded severalfold differences in the $\mathrm{IC}_{50}$ values for the same drug because different substrates were used in these tests $^{16,17}$.

Once a new chemical entity (NCE) is clinically tested, the assessment of drug-drug interactions is a crucial part of such studies. Such studies are increasingly being supported by quantitative in silico predictions of altered pharmacokinetics of an $\mathrm{NCE}^{18}$. Such approaches rely heavily on parameters determined in vitro. As an alternative method, imaging methodologies for studying drug (or solute) transport in vivo are rapidly emerging ${ }^{19-21}$. These approaches should also become useful for determining drug-drug interactions at the level of (uptake) transporters ${ }^{22}$.

\section{Drug transporters and imaging}

Imaging of the liver involves magnetic resonance imaging, positron emission tomography (PET), and scintigraphy and implies the use of labeled molecules ${ }^{23}$. Dynamic imaging (i.e. with agents) of the liver may be aimed at obtaining insights into organ function, e.g. before performing major liver resections ${ }^{24}$, or to study the uptake of solutes into the liver, e.g. for studying drug transport ${ }^{20}$. PET studies have the advantage that they are performed under microdosing conditions and hence PET substrates are unlikely to exhibit pharmacological or even toxicological effects. In recent years, PET tracers for several drugs such as statins, metformin, telmisartan, or glyburide were developed and tested in animal models ${ }^{20}$. (15R)- ${ }^{11} \mathrm{C}$-TIC-Me was developed to visualize prostacyclin receptors by PET and was used in healthy volunteers for monitoring hepatobiliary transport ${ }^{22}$. One of the major classes of solutes handled by the liver are the bile salts. Cholylsarcosine is a synthetic bile salt analogue ${ }^{25}$ and can be modified to become a PET tracer ${ }^{26}$. This makes the molecule an ideal tool for non-invasively studying transport processes in hepatocytes involving bile salt transporters. In pigs, $\left[N\right.$-methyl $\left.-{ }^{11} \mathrm{C}\right]$ cholylsarcosine was used to determine hepatobiliary secretion kinetics ${ }^{27}$. $\left[N\right.$-methyl $\left.-{ }^{11} \mathrm{C}\right]$ cholylsarcosine was found to be concentrated 4000-fold from blood to bile. Importantly, no accumulation of cholylsarcosine was found in hepatocytes, demonstrating the concerted action of the basolateral uptake systems for bile salts, which in humans are represented by the sodiumtaurocholate cotransporting polypeptide (NTCP), three OATPs, and the canalicular bile salt export pump BSEP ${ }^{28}$. The canalicular efflux of cholylsarcosine was 180 times higher than the backflux from hepatocytes into the sinusoids, demonstrating the efficiency of transcellular bile salt flux under normal physiological conditions.

Transport proteins may have altered expression in various forms of liver diseases ${ }^{29}$. Consequently, changes in the hepatocellular uptake of imaging tracers may indicate an altered expression of the respective uptake or efflux transporters. It should, however, be kept in mind that liver disease may also alter the energetics of hepatocytes, which in turn can affect driving forces for transporters and consequently impact the uptake of imaging tracers. For example, hepatobiliary scintigraphy can be used to assess the liver functional volume before liver resections $s^{30,31}$. Classically, indocyanine green clearance has been used for assessing dynamic liver function before 
liver surgery and has been reported to be superior to the Child-Pugh classification $^{32}$. One of the parameters used for Child-Pugh scoring is the total serum bilirubin level. It is known that bilirubin uptake into hepatocytes shares common (drug) transporters with indocyanine green ${ }^{33}$, supporting the role of drug transporters in imaging.

\section{New drug transporters}

As briefly outlined above, several members of the SLC families, in particular OATs and OCTs of the SLC22A and OATPs of the SLCO families, are well-characterized drug transporters ${ }^{34}$. Some of these transporters are routinely included in drug-drug interaction tests for $\mathrm{NCEs}^{5,35}$. However, it is not yet known definitively whether additional transporters, especially transporters that have been characterized with respect to their normal physiological roles in maintaining solute movement across the hepatocyte membrane, are also involved in drug transport in and out of hepatocytes. For example, once characterized as the major hepatocellular uptake system for conjugated bile acids, NTCP was shown in 2006 to be able to transport rosuvastatin ${ }^{36}$ and potentially account for up to $35 \%$ of rosuvastatin uptake in isolated human hepatocytes. In 2007, Shin and coworkers ${ }^{37}$ identified and characterized a novel member of the SLC22A family, namely OAT7 (SLC22A9), as a liverspecific OAT that is expressed at the sinusoidal membrane and was able to transport estrone-3-sulfate and dehydroepiandrosterone sulfate. In addition, transport of these sulfates was inhibited by several sulfated but not glucuronidated xenobiotics, and short-chain fatty acids were identified as potential physiological substrates of this transporter ${ }^{37}$. Recently, in an attempt to better characterize the expression and function of OAT7, pravastatin was identified as the first drug substrate of OAT $7^{38}$. It was previously shown that besides several OATPs ${ }^{34}$, OAT3 is also able to transport pravastatin and rosuvastati ${ }^{39}$. Thus, we cannot rule out that additional transporters within a given family that have so far not demonstrated to be drug transporters could also be new drug transporters. Hence, new drug transporters may still be waiting to be discovered in hepatocytes.

\section{Drug transporters and regulatory guidance}

Given the established role of transporters in drug disposition and pharmacokinetic drug-drug interactions, both the Food and Drug Administration (USA) and the European Medicines Agency as well as the Pharmaceuticals and Medical Devices Agency (Japan) have established guidelines on the investigation of the role of a specific set of transporters when developing $\mathrm{NCEs}^{40}$. These guidelines require the determination of kinetic properties of transporters, e.g. the determination of $\mathrm{IC}_{50}$ values for NCEs. Unfortunately, the setup of transport assays will impact the numeric values of transporter parameters. This has been illustrated by a recent study, which used a common set of inhibitors for the multidrug resistance protein 1 $(A B C B 1)$ in 23 laboratories for the determination of the $\mathrm{IC}_{50}$ values of these compounds. The outcome of this study is rather sobering in that the largest difference in $\mathrm{IC}_{50}$ values between the different laboratories for one inhibitor was 796-fold ${ }^{41}$. As such, $\mathrm{IC}_{50}$ values are one of the parameters to be considered for the prediction of potential drug-drug interactions; aberrant $\mathrm{IC}_{50}$ values may lead to false negative or false positive predictions ${ }^{42}$. The importance of proper experimental conditions has also been documented in a recent study where the effects of the unstirred water layer on the apparent $\mathrm{K}_{\mathrm{m}}$ values for OCT2- and MATE1-mediated substrate transport were investigated $^{43}$. The authors concluded that increasing the expression levels of the expressed transporters in mammalian cells to increase the signal-to-noise ratio actually might lead to an overestimation of the apparent $\mathrm{K}_{\mathrm{m}}$ values by 2- to 10-fold.

Such results clearly demonstrate a need for (some) harmonization of experimental conditions when kinetic parameters of transporter systems are being determined. Currently, such attempts are still at the beginning ${ }^{4-46}$. In addition to following standard rules for kinetic experiments, it is crucial for obtaining reproducible results to perform the transport experiments under conditions of initial linear uptake rates ${ }^{47}$. If the latter condition is not fulfilled, estimated kinetic parameters may be invalid ${ }^{48}$.

\section{Deorphanizing SLC transporters}

Up to $10 \%$ of all human genes may have transport- or transporterrelated functions ${ }^{7}$. Currently, 456 SLC transporters, which belong to 52 subfamilies, are known in the human genome ${ }^{49}$. Many of these SLC transporters are only marginally or not characterized at all. Although OATPs are normally called drug transporters, this notion is mainly because of the fact that the liver-expressed OATP1B 1 and OATP1B3 are able to mediate the uptake of numerous drugs when expressed in vitro and polymorphisms in these two transporters are known to affect the pharmacokinetics of the drugs they transport. Besides these two best-characterized OATPs, there are nine additional genes in the human genome encoding OATPs and one pseudogene ${ }^{50}$. Several of the encoded OATPs have been more or less well characterized and are known to be able to transport endobiotics as well as xenobiotics ${ }^{15,50}$. Among the better characterized are the multi-specific OATP1A2 and OATP2B1, and the transporters with a narrower substrate specificity like OATP1C1 or the prostaglandin transporter OATP2A $1^{34}$. There are fewer reports characterizing the function of OATP3A1, OATP4A1, and OATP4C1, while for OATP5A1 and OATP6A1 no function has been reported so far and therefore OATP5A1 and OATP6A1 can be considered orphan transporters. Given that there are several reports that document OATP5A1 and OATP6A1 expression in cancer ${ }^{51-53}$, the elucidation of their function could be an important step towards better diagnosis or therapy for cancers expressing these OATPs. A recent study describes the biochemical characterization and expression of OATP5A1 in mature dendritic cells and whereby OATP5A1 seems to affect cell proliferation ${ }^{54}$. However, no transport function was identified, and as long as no other biological function is associated with OATP5A1, it still needs to be deorphanized.

Similar to the OATP family with two orphan transporters, there are several orphan transporters in the SLC10A family that contain the hepatocellular sodium-dependent bile acid uptake transporter NTCP (SLC10A1), the apical sodium-dependent bile acid transporter ASBT (SLC1OA2) expressed in the ileum, kidney, and cholangiocytes, and the sodium-dependent organic anion transporter SOAT $(S L C 10 A 6)^{55}$. While these three transporters have been well 
characterized, this family contains four additional proteins, namely P3 (SLC10A3), P4 (SLC10A4), P5 (SLC10A5), and P7 (SLC10A7), with mostly unknown function. To try to understand the function of SLC10A4 (a "transporter" expressed in humans in the developing ventral mesencephalon ${ }^{56}$ and in rats in cholinergic and monoaminergic neurons ${ }^{57}$ ), mice lacking SLC10A4 protein were recently characterized ${ }^{58-60}$. No direct transporter function could be demonstrated for SLC10A4, but its absence reduced dopamine, noradrenaline, serotonin, and acetylcholine content in certain brain regions. These knockout mice also showed characteristics that are similar to symptoms of neurodegenerative disease and, as a consequence, SLC10A4 might become a novel target for neurological and mental diseases. An additional example is SLC32F2, which was known to be highly expressed in tumors ${ }^{61}$, but only recently it was demonstrated that this transporter may mediate cellular uptake of the anticancer drug YM155 ${ }^{62}$. Furthermore, SLC38A9 was only recently identified as an important component of the lysosomal amino acid sensing machinery and to be involved in the control of the mammalian target of rapamycin complex $1^{63}$. These few examples highlight the pressing need for "deorphanizing" the SLC transporters completely. Possible methods may include the generation of knockout mice as described for SLC10A $4^{58,60}$, the use of haploid genetic screens, which was successful in the identification of a function for SLC35F2 $2^{62}$, and possibly siRNA screens when a transporter for a given function needs to be identified.

\section{Outlook}

There is clearly a need for obtaining more information on the role of SLC transporters in drug transport as well as for deorphanizing SLC transporters ${ }^{49}$. The identification of substrates for transporters may not be straightforward, e.g. SLC10A4 is, to the best of our knowledge, a transporter whose substrates have not been identified conclusively yet. While one group reported that protease activation of SLC10A4 makes this protein a bile acid transporter ${ }^{64}$, another group could not reproduce this finding and also did not find evidence for a transport activity of neuromodulators ${ }^{65}$. One possible explanation for these different findings is the use of different experimental systems. Alternatively, the fact that NTCP was found to form homodimers and heterodimers ${ }^{66}$ might indicate that SLC10A4 may need an interacting protein to function properly. So far, very limited information on the impact of homodimer and heterodimer formation on transport activity and substrate specificity of transport proteins is available. With the development of very powerful tools for the determination of protein interactomes ${ }^{67}$ including membrane proteins ${ }^{68}$, a non-targeted search for interacting partners for orphan transporters might become a feasible option in the near future. In support of this, the determination of the interactome of yeast $\mathrm{ABC}$ transporters has yielded a wealth of information for the physiological role and regulation of these transporters ${ }^{69}$. Rat multidrug-resistance-associated protein 6 (MRP6) (Abcc6) was cloned in 2000 and BQ123 was identified as the only substrate ${ }^{70}$.
In the same year, mutations in $A B C C 6$ were found to cause pseudoxanthoma elasticum ${ }^{71,72}$. Human $A B C C 6$ was found to transport glutathione conjugates and leukotrienes ${ }^{73}$. However, a physiological substrate for MRP6 remained enigmatic ${ }^{74}$. An elegant metabolomics approach using vesicles derived from HEK293 cells overexpressing MRP6 led to the identification of ATP as a potential physiological substrate for MRP6 $^{75,76}$. This finding demonstrates the power of metabolomics in identifying substrates for drug and orphan transporters.

The channeling of substrates for energy production through complexes of sequential metabolic enzymes has been known for quite some time ${ }^{77,78}$. The role of transporter-metabolizing enzyme interactions in pharmacokinetics as well as in drug-drug interactions is starting to gain attention ${ }^{18,79}$. The clinical relevance of this approach is illustrated by a study in which rifampicin was tested as an OATP inhibitor as well as an inducer of CYP3A4. As an OATP inhibitor, rifampicin increased the trough concentration for the victim drug bosentan, while as an inducer of CYP3A4 it decreased the AUC for bosentan ${ }^{80}$.

Information on transporter expression levels is an important prerequisite for the prediction of pharmacokinetics and drug-drug interactions occurring at hepatocellular transporters ${ }^{81}$. Absolute quantification of transporters by proteomics resulted in first data $^{82,83}$. From the data published so far, it seems that under normal physiological conditions a considerable interindividual variability of transporter levels exists. This variability often exceeds a 10-fold range. To what extent technical issues, e.g. the condition of liver biopsies used for transporter quantification, contribute to this observation remains to be determined. Furthermore, it should be kept in mind that many forms of (liver) disease have an impact on transporter expression levels ${ }^{29,84}$.

\section{Abbreviations}

ABC, ATP-binding cassette; CYP, cytochrome P450; MRP, multidrug resistance-associated protein; NCE, new chemical entity; OAT, organic anion transporter; OATP, organic anion transporting polypeptide; OCT, organic cation transporter; PET, positron emission tomography; SLC, solute carrier.

\section{Competing interests}

The authors declare that they have no competing interests.

\section{Grant information}

Bruno Stieger is supported by the Swiss National Science foundation (grant 310030_166563) and by the SNF National Center for Competence TransCure (University of Berne, Berne, Switzerland). Bruno Hagenbuch is funded by the National Institutes of Health grant GM077336. 
1. Nigam SK: What do drug transporters really do? Nat Rev Drug Discov. 2015; 14(1): 29-44.

PubMed Abstract | Publisher Full Text | Free Full Text

2. Kell DB, Dobson PD, Oliver SG: Pharmaceutical drug transport: the issues and the implications that it is essentially carrier-mediated only. Drug Discov Today. 2011; 16(15-16): 704-14.

PubMed Abstract | Publisher Full Text

3. Kell DB, Oliver SG: How drugs get into cells: tested and testable predictions to help discriminate between transporter-mediated uptake and lipoidal bilayer diffusion. Front Pharmacol. 2014; 5: 231.

PubMed Abstract | Publisher Full Text | Free Full Text

4. Patel M, Taskar KS, Zamek-Gliszczynski MJ: Importance of Hepatic Transporters in Clinical Disposition of Drugs and Their Metabolites. J Clin Pharmacol. 2016; 56(Suppl 7): S23-39.

PubMed Abstract | Publisher Full Text

5. Hillgren KM, Keppler D, Zur AA, et al:: Emerging transporters of clinical importance: an update from the International Transporter Consortium. Clin Pharmacol Ther. 2013; 94(1): 52-63.

PubMed Abstract | Publisher Full Text

6. Pfeifer ND, Hardwick RN, Brouwer KL: Role of hepatic efflux transporters in regulating systemic and hepatocyte exposure to xenobiotics. Annu Rev Pharmacol Toxicol. 2014; 54: 509-35.

PubMed Abstract | Publisher Full Text

7. Hediger MA, Clémençon B, Burrier RE, et al:: The ABCs of membrane transporters in health and disease (SLC series): introduction. Mol Aspects Med. 2013; 34(2-3): 95-107.

PubMed Abstract | Publisher Full Text | Free Full Text

8. Konig J, Müller F, Fromm MF: Transporters and drug-drug interactions: important determinants of drug disposition and effects. Pharmacol Rev. 2013; 65(3): 944-66.

PubMed Abstract | Publisher Full Text

9. Koepsell $\mathrm{H}$ : Role of organic cation transporters in drug-drug interaction. Expert Opin Drug Metab Toxicol. 2015; 11(10): 1619-33.

PubMed Abstract | Publisher Full Text

10. F Bohnert T, Patel A, Templeton I, et al:: Evaluation of a New Molecular Entity as a Victim of Metabolic Drug-Drug Interactions-an Industry Perspective. Drug Metab Dispos. 2016; 44(8): 1399-423.

PubMed Abstract | Publisher Full Text | F1000 Recommendation

11. Wang B, Yang LP, Zhang XZ, et al.: New insights into the structural characteristics and functional relevance of the human cytochrome P450 2D6 enzyme. Drug Metab Rev. 2009; 41(4): 573-643.

PubMed Abstract | Publisher Full Text

12. Hong M: Biochemical studies on the structure-function relationship of major drug transporters in the ATP-binding cassette family and solute carrier family. Adv Drug Deliv Rev. 2016; pii: S0169-409X(16)30187-9. PubMed Abstract | Publisher Full Text

13. F An F, Qu Y, Liu X, et al.: Organ-on-a-Chip: New Platform for Biological Analysis. Anal Chem Insights. 2015; 10: 39-45.

PubMed Abstract | Publisher Full Text | Free Full Text | F1000 Recommendation

14. F An F, Qu Y, Luo Y, et al:: A Laminated Microfluidic Device for Comprehensive Preclinical Testing in the Drug ADME Process. Sci Rep. 2016; 6: 25022.

PubMed Abstract | Publisher Full Text | Free Full Text | F1000 Recommendation

15. Hagenbuch B, Stieger B: The SLCO (former SLC21) superfamily of transporters. Mol Aspects Med. 2013; 34(2-3): 396-412.

PubMed Abstract | Publisher Full Text | Free Full Text

16. Izumi S, Nozaki Y, Komori T, et al.: Substrate-dependent inhibition of organic anion transporting polypeptide 1B1: comparative analysis with prototypical probe substrates estradiol-17 $\beta$-glucuronide, estrone-3-sulfate, and sulfobromophthalein. Drug Metab Dispos. 2013; 41(10): 1859-66. PubMed Abstract | Publisher Full Text

17. F Izumi S, Nozaki Y, Maeda K, et al.: Investigation of the impact of substrate selection on in vitro organic anion transporting polypeptide 1B1 inhibition profiles for the prediction of drug-drug interactions. Drug Metab Dispos. 2015; 43(2): 235-47.

PubMed Abstract | Publisher Full Text | F1000 Recommendation

18. Varma MV, Pang KS, Isoherranen N, et al:: Dealing with the complex drug-drug interactions: towards mechanistic models. Biopharm Drug Dispos. 2015; 36(2): 71-92.

PubMed Abstract | Publisher Full Text

19. Mann A, Semenenko I, Meir M, et al.: Molecular Imaging of Membrane Transporters' Activity in Cancer: a Picture is Worth a Thousand Tubes. AAPS J. 2015; 17(4): 788-801.

PubMed Abstract | Publisher Full Text | Free Full Text

20. F Testa A, Zanda M, Elmore CS, et al:: PET Tracers To Study Clinically Relevant Hepatic Transporters. Mol Pharm. 2015; 12(7): 2203-16. PubMed Abstract | Publisher Full Text | F1000 Recommendation

21. F Langer O: Use of PET Imaging to Evaluate Transporter-Mediated Drug-Drug
Interactions. J Clin Pharmacol. 2016; 56(Suppl 7): S143-56.

PubMed Abstract | Publisher Full Text | F1000 Recommendation

22. Takashima $\mathrm{T}$, Kitamura $\mathrm{S}, \mathrm{Wada} \mathrm{Y}$, et al:: PET imaging-based evaluation of hepatobiliary transport in humans with (15R)- ${ }^{11} \mathrm{C}-\mathrm{TIC}-\mathrm{Me}$. J Nucl Med. 2012; 53(5): 741-8.

PubMed Abstract | Publisher Full Text

23. Stieger B, Unadkat JD, Prasad B, et al:: Role of (drug) transporters in imaging in health and disease. Drug Metab Dispos. 2014; 42(12): 2007-15.

PubMed Abstract | Publisher Full Text

24. Cieslak KP, Runge JH, Heger M, et al: New perspectives in the assessment of future remnant liver. Dig Surg. 2014; 31(4-5): 255-68. PubMed Abstract | Publisher Full Text

25. Schmassmann A, Fehr HF, Locher J, et al.: Cholylsarcosine, a new bile acid analogue: metabolism and effect on biliary secretion in humans. Gastroenterology. 1993; 104(4): 1171-81.

PubMed Abstract

26. Frisch $\mathrm{K}$, Jakobsen $\mathrm{S}$, Sørensen $\mathrm{M}$, et al.: [N-methyl- $\left.{ }^{11} \mathrm{C}\right]$ Cholylsarcosine, a novel bile acid tracer for PET/CT of hepatic excretory function: radiosynthesis and proof-of-concept studies in pigs. J Nucl Med. 2012; 53(5): 772-8. PubMed Abstract | Publisher Full Text | Free Full Text

27. F Sørensen M, Munk OL, Ørntoft NW, et al:: Hepatobiliary Secretion Kinetics of Conjugated Bile Acids Measured in Pigs by ${ }^{11} \mathrm{C}$-Cholylsarcosine PET. J NuCl Med. 2016; 57(6): 961-6.

PubMed Abstract | Publisher Full Text | F1000 Recommendation

28. Stieger B: The role of the sodium-taurocholate cotransporting polypeptide (NTCP) and of the bile salt export pump (BSEP) in physiology and pathophysiology of bile formation. Handb Exp Pharmacol. 2011; (201): 205-59. PubMed Abstract | Publisher Full Text

29. Pollheimer MJ, Fickert $P$, Stieger B: Chronic cholestatic liver diseases: clues from histopathology for pathogenesis. Mol Aspects Med. 2014; 37: 35-56. PubMed Abstract | Publisher Full Text

30. de Graaf W, van Lienden KP, van Gulik TM, et al.: 99mTc-mebrofenin hepatobiliary scintigraphy with SPECT for the assessment of hepatic function and liver functional volume before partial hepatectomy. J Nucl Med. 2010; 51(2): 229-36. PubMed Abstract | Publisher Full Text

31. Bennink RJ, de Graaf W, van Gulik TM: Toward a total and regional scintigraphic liver function test enabling assessment of future remnant liver function. NuCl Med Commun. 2011; 32(8): 669-71.

PubMed Abstract | Publisher Full Text

32. Hoekstra LT, de Graaf W, Nibourg GA, et al.: Physiological and biochemical basis of clinical liver function tests: a review. Ann Surg. 2013; 257(1): 27-36. PubMed Abstract | Publisher Full Text

33. Stieger $\mathrm{B}$, Heger $\mathrm{M}$, de Graaf $\mathrm{W}$, et al.: The emerging role of transport systems in liver function tests. Eur $J$ Pharmacol. 2012; 675(1-3): 1-5.

PubMed Abstract | Publisher Full Text

34. Roth M, Obaidat A, Hagenbuch B: OATPs, OATs and OCTs: the organic anion and cation transporters of the SLCO and SLC22A gene superfamilies. Br J Pharmacol. 2012; 165(5): 1260-87.

PubMed Abstract | Publisher Full Text | Free Full Text

35. International Transporter Consortium, Giacomini KM, Huang SM, et al:: Membrane transporters in drug development. Nat Rev Drug Discov. 2010; 9(3): 215-36. PubMed Abstract | Publisher Full Text | Free Full Text

36. Ho RH, Tirona RG, Leake BF, et al: Drug and bile acid transporters in rosuvastatin hepatic uptake: function, expression, and pharmacogenetics. Gastroenterology. 2006; 130(6): 1793-806 PubMed Abstract | Publisher Full Text

37. F Shin HJ, Anzai N, Enomoto A, et al:: Novel liver-specific organic anion transporter OAT7 that operates the exchange of sulfate conjugates for short chain fatty acid butyrate. Hepatology. 2007; 45(4): 1046-55. PubMed Abstract | Publisher Full Text | F1000 Recommendation

38. F Emami Riedmaier A, Burk O, van Eijck BA, et al.: Variability in hepatic expression of organic anion transporter 7/SLC22A9, a novel pravastatin uptake transporter: impact of genetic and regulatory factors. Pharmacogenomics J. 2016; 16(4): 341-51.

PubMed Abstract | Publisher Full Text | F1000 Recommendation

39. Burckhardt G, Burckhardt BC: In vitro and in vivo evidence of the importance of organic anion transporters (OATs) in drug therapy. Handb Exp Pharmacol. 2011; (201): 29-104

PubMed Abstract | Publisher Full Text

40. Arya V, Kiser JJ: Role of Transporters in Drug Development. J Clin Pharmacol. 2016; 56(Suppl 7): S7-S10.

PubMed Abstract | Publisher Full Text

41. F Bentz J, O'Connor MP, Bednarczyk D, et al:: Variability in P-glycoprotein inhibitory potency $\left(\mathrm{IC}_{50}\right)$ using various in vitro experimental systems: implications for universal digoxin drug-drug interaction risk assessment decision criteria. Drug Metab Dispos. 2013; 41(7): 1347-66. decision criteria. Drug Metab Dispos. 2013; 41(7): 1347-66.
PubMed Abstract | Publisher Full Text | Free Full Text | F1000 Recommendation

42. Ellens H, Deng S, Coleman J, et al:: Application of receiver operating 
characteristic analysis to refine the prediction of potential digoxin drug interactions. Drug Metab Dispos. 2013; 41(7): 1367-74.

PubMed Abstract | Publisher Full Text | Free Full Text

43. F Shibayama T, Morales M, Zhang X, et al:: Unstirred Water Layers and the Kinetics of Organic Cation Transport. Pharm Res. 2015; 32(9): 2937-49. PubMed Abstract | Publisher Full Text | Free Full Text | F1000 Recommendation

44. Brouwer KL, Keppler D, Hoffmaster KA, et al:: In vitro methods to support transporter evaluation in drug discovery and development. Clin Pharmacol Ther. 2013; 94(1): 95-112.

PubMed Abstract | Publisher Full Text

45. Zamek-Gliszczynski MJ, Lee CA, Poirier A, et al.: ITC recommendations for transporter kinetic parameter estimation and translational modeling of transport-mediated PK and DDIs in humans. Clin Pharmacol Ther. 2013; 94(1): 64-79.

PubMed Abstract | Publisher Full Text | Free Full Text

46. Lee CA, Kalvass JC, Galetin A, et al:: ITC commentary on the prediction of digoxin clinical drug-drug interactions from in vitro transporter assays. Clin Pharmacol Ther. 2014; 96(3): 298-301.

PubMed Abstract | Publisher Full Text

47. Murer H, Biber J, Gmaj P, et al:: Cellular mechanisms in epithelial transport: Advantages and disadvantages of studies with vesicles. Mol Physiol. 1984; 6(1-2): 55-82. Reference Source

48. Tachibana $\mathrm{T}$, Kitamura S, Kato M, et al:: Model analysis of the concentrationdependent permeability of P-gp substrates. Pharm Res. 2010; 27(3): 442-6. PubMed Abstract | Publisher Full Text

49. César-Razquin A, Snijder B, Frappier-Brinton T, et al:: A Call for Systematic Research on Solute Carriers. Cell. 2015; 162(3): 478-87. PubMed Abstract | Publisher Full Text

50. Stieger B, Hagenbuch B: Organic anion-transporting polypeptides. Curr Top Membr. 2014; 73: 205-32.

PubMed Abstract | Publisher Full Text | Free Full Text

51. F Brenner S, Klameth L, Riha J, et al.: Specific expression of OATPs in primary small cell lung cancer (SCLC) cells as novel biomarkers for diagnosis and therapy. Cancer Lett. 2015; 356(2 Pt B): 517-24.

PubMed Abstract | Publisher Full Text | F1000 Recommendation

52. Kindla J, Rau TT, Jung R, et al.: Expression and localization of the uptake transporters OATP2B1, OATP3A1 and OATP5A1 in non-malignant and malignant breast tissue. Cancer Biol Ther. 2011; 11(6): 584-91. PubMed Abstract | Publisher Full Text

53. Lee SY, Williamson B, Caballero OL, et al:: Identification of the gonad-specific anion transporter SLCO6A1 as a cancer/testis (CT) antigen expressed in human lung cancer. Cancer Immun. 2004; 4: 13.

PubMed Abstract

54. Sebastian K, Detro-Dassen S, Rinis N, et al:: Characterization of SLCO5A1/ OATP5A1, a solute carrier transport protein with non-classical function. PLOS One. 2013; 8(12): e83257.

PubMed Abstract | Publisher Full Text | Free Full Text

55. Claro da Silva T, Polli JE, Swaan PW: The solute carrier family 10 (SLC10): beyond bile acid transport. Mol Aspects Med. 2013; 34(2-3): 252-69. PubMed Abstract | Publisher Full Text | Free Full Text

56. Jorgensen JR, Juliusson B, Henriksen KF, et al.: Identification of novel genes regulated in the developing human ventral mesencephalon. Exp Neurol. 2006 198(2): 427-37.

PubMed Abstract | Publisher Full Text

57. Geyer J, Fernandes CF, Döring B, et al:: Cloning and molecular characterization of the orphan carrier protein SIc10a4: expression in cholinergic neurons of the rat central nervous system. Neuroscience. 2008; 152(4): 990-1005. PubMed Abstract | Publisher Full Text

58. Zelano J, Mikulovic S, Patra K, et al:: The synaptic protein encoded by the gene SIc10A4 suppresses epileptiform activity and regulates sensitivity to cholinergic chemoconvulsants. Exp Neurol. 2013; 239: 73-81. PubMed Abstract | Publisher Full Text

59. F Larhammar M, Patra K, Blunder M, et al.: SLC10A4 is a vesicular amineassociated transporter modulating dopamine homeostasis. Biol Psychiatry. 2015; 77(6): 526-36.

PubMed Abstract | Publisher Full Text | F1000 Recommendation

60. F Melief EJ, Gibbs JT, Li X, et al.: Characterization of cognitive impairment and neurotransmitter changes in a novel transgenic mouse lacking SIc10a4. Neuroscience. 2016; 324: 399-406.

PubMed Abstract | Publisher Full Text | Free Full Text | F1000 Recommendation

61. Bu L, Jiang G, Yang F, et al.: Highly expressed SLC35F2 in non-small cell lung cancer is associated with pathological staging. Mol Med Rep. 2011; 4(6): 1289-93. PubMed Abstract | Publisher Full Text

62. F Winter GE, Radic B, Mayor-Ruiz C, et al:: The solute carrier SLC35F2 enables YM155-mediated DNA damage toxicity. Nat Chem Biol. 2014; 10(9): 768-73. PubMed Abstract | Publisher Full Text | Free Full Text | F1000 Recommendation

63. F Rebsamen M, Pochini L, Stasyk T, et al:: SLC38A9 is a component of the lysosomal amino acid sensing machinery that controls mTORC1. Nature. 2015; 519(7544): 477-81.

PubMed Abstract | Publisher Full Text | Free Full Text | F1000 Recommendation
64. Abe $\mathrm{T}$, Kanemitu $\mathrm{Y}$, Nakasone $\mathrm{M}$, et al.: SLC10A4 is a protease-activated transporter that transports bile acids. J Biochem. 2013; 154(1): 93-101. PubMed Abstract | Publisher Full Text

65. F Schmidt S, Moncada M, Burger S, et al.: Expression, sorting and transport studies for the orphan carrier SLC10A4 in neuronal and non-neuronal cell lines and in Xenopus laevis oocytes. BMC Neurosci. 2015; 16: 35. PubMed Abstract | Publisher Full Text | Free Full Text | F1000 Recommendation

66. Bijsmans IT, Bouwmeester RA, Geyer J, et al:: Homo- and hetero-dimeric architecture of the human liver $\mathrm{Na}(+)$-dependent taurocholate co-transporting protein. Biochem J. 2012; 441(3): 1007-15.

PubMed Abstract | Publisher Full Text

67. Yachie N, Petsalaki E, Mellor JC, et al.: Pooled-matrix protein interaction screens using Barcode Fusion Genetics. Mol Syst Biol. 2016; 12(4): 863 PubMed Abstract | Publisher Full Text | Free Full Text

68. Snider J, Stagljar I: Membrane Yeast Two-Hybrid (MYTH) Mapping of Full-Length Membrane Protein Interactions. Cold Spring Harb Protoc. 2016; 2016(1): pdb.top077560.

PubMed Abstract | Publisher Full Tex

69. F Snider J, Hanif A, Lee ME, et al:: Mapping the functional yeast ABC transporter interactome. Nat Chem Biol. 2013; 9(9): 565-72.

PubMed Abstract | Publisher Full Text | Free Full Text | F1000 Recommendation

70. Madon J, Hagenbuch B, Landmann L, et al: Transport function and hepatocellular localization of mrp6 in rat liver. Mol Pharmacol. 2000; 57(3): 634-41. PubMed Abstract

71. Ringpfeil F, Lebwohl MG, Christiano AM, et al.: Pseudoxanthoma elasticum: mutations in the MRP6 gene encoding a transmembrane ATP-binding cassette (ABC) transporter. Proc Natl Acad Sci U S A. 2000; 97(11): 6001-6. PubMed Abstract | Publisher Full Text | Free Full Text

72. Bergen AA, Plomp AS, Schuurman EJ, et al:: Mutations in ABCC6 cause pseudoxanthoma elasticum. Nat Genet. 2000; 25(2): 228-31. PubMed Abstract | Publisher Full Text

73. Iliás A, Urbán Z, Seidl TL, et al.: Loss of ATP-dependent transport activity in pseudoxanthoma elasticum-associated mutants of human ABCC6 (MRP6). J Biol Chem. 2002; 277(1): 16860-7.

PubMed Abstract | Publisher Full Text

74. Borst $P$, van de Wetering $K$, Schlingemann R: Does the absence of ABCC6 (multidrug resistance protein 6) in patients with Pseudoxanthoma elasticum prevent the liver from providing sufficient vitamin $\mathrm{K}$ to the periphery? Cell Cycle. 2008; 7(11): 1575-9.

PubMled Abstract | Publisher Full Text

75. F Jansen RS, Küçükosmanoglu A, de Haas M, et al:: ABCC6 prevents ectopic mineralization seen in pseudoxanthoma elasticum by inducing cellula nucleotide release. Proc Natl Acad Sci U S A. 2013; 110(50): 20206-11. PubMed Abstract | Publisher Full Text | Free Full Text | F1000 Recommendation

76. F Jansen RS, Duijst S, Mahakena S, et al:: ABCC6-mediated ATP secretion by the liver is the main source of the mineralization inhibitor inorganic pyrophosphate in the systemic circulation-brief report. Arterioscler Thromb Vasc Biol. 2014; 34(9): 1985-9.

PubMed Abstract | Publisher Full Text | F1000 Recommendation

77. Beeckmans S, Kanarek L: Enzyme-enzyme interactions as modulators of the metabolic flux through the citric acid cycle. Biochem Soc Symp. 1987; 54 163-72.

PubMed Abstract

78. Srere PA, Ovadi J: Enzyme-enzyme interactions and their metabolic role. FEBS Lett. 1990; 268(2): 360-4.

PubMed Abstract | Publisher Full Tex

79. Varma MV, El-Kattan AF: Transporter-Enzyme Interplay: Deconvoluting Effects of Hepatic Transporters and Enzymes on Drug Disposition Using Static and Dynamic Mechanistic Models. J Clin Pharmacol. 2016; 56(Suppl 7): S99-S109.

PubMed Abstract | Publisher Full Text

80. van Giersbergen PL, Treiber A, Schneiter R, et al: Inhibitory and inductive effects of rifampin on the pharmacokinetics of bosentan in healthy subjects. Clin Pharmacol Ther. 2007; 81(3): 414-9. PubMed Abstract | Publisher Full Text

81. Li R, Barton HA, Varma MV: Prediction of pharmacokinetics and drug-drug interactions when hepatic transporters are involved. Clin Pharmacokinet 2014. 53(8): 659-78.

PubMed Abstract | Publisher Full Text

82. Ohtsuki S, Uchida Y, Kubo Y, et al:: Quantitative targeted absolute proteomicsbased ADME research as a new path to drug discovery and development: methodology, advantages, strategy, and prospects. J Pharm Sci. 2011; 100(9): $3547-59$

PubMed Abstract | Publisher Full Text

83. Prasad B, Unadkat JD: Optimized approaches for quantification of drug transporters in tissues and cells by MRM proteomics. AAPS J. 2014; 16(4) $634-48$.

PubMed Abstract | Publisher Full Text | Free Full Text

84. Atilano-Roque A, Roda G, Fogueri U, et al.: Effect of Disease Pathologies on Transporter Expression and Function. J Clin Pharmacol. 2016; 56(Suppl 7): S205-21.

PubMed Abstract | Publisher Full Text 


\section{Open Peer Review}

\section{Current Peer Review Status:}

\section{Editorial Note on the Review Process}

Faculty Reviews are review articles written by the prestigious Members of Faculty Opinions. The articles are commissioned and peer reviewed before publication to ensure that the final, published version is comprehensive and accessible. The reviewers who approved the final version are listed with their names and affiliations.

\section{The reviewers who approved this article are:}

\section{Version 1}

\section{Richard Kim}

University of Western Ontario, London, ON, Canada

Competing Interests: No competing interests were disclosed.

\section{Amal Khalil Kaddoumi}

University of Louisiana at Monroe, Monroe, LA, USA

Competing Interests: No competing interests were disclosed.

The benefits of publishing with F1000Research:

- Your article is published within days, with no editorial bias

- You can publish traditional articles, null/negative results, case reports, data notes and more

- The peer review process is transparent and collaborative

- Your article is indexed in PubMed after passing peer review

- Dedicated customer support at every stage

For pre-submission enquiries, contact research@f1000.com 